\title{
Role of Nuclear Energy to a Low Carbon Society
}

\author{
Shinzo SAITO1, Masuro OGAWA and Ryutaro HINO \\ Japan Atomic Energy Research Institute \\ (At present : Japan Atomic Energy Agency) \\ ${ }^{1}$ At present: Radiation Application Development Association \\ Japan
}

\section{Introduction}

More than 10 billion tons of oil equivalent energy are consumed a year in the world in the present time and over $80 \%$ of it is provided by fossil fuels such as coal, oil and natural gas. Many specialists, institutes, international agencies and organizations have foreseen or estimated an increase of energy consumption in future, remaining fossil fuel resources, and the period of consumption of them.

On the other hand, global warming due to green house gases (GHG) emissions, especially carbon dioxide $\left(\mathrm{CO}_{2}\right)$ emitted by burning of fossil fuels has become a serious issue. The IPCC (Inter-governmental Panel on Climate Change) opened their Fourth Assessment Report [1] to the public last year indicating that anthropogenic warming over the last three decades has likely had a discernible influence at the global scale on observed changes in many physical and biological systems. The report also describes that altered frequencies and intensities of extreme weather, together with sea level rise, are expected to have mostly adverse effects on natural and human systems.

Most of the countries in the world confirmed the significance of the Fourth Assessment Report of the IPCC as providing the most comprehensive assessment of the science and encouraged the continuation of the science-based approach that should guide our climate protection efforts. The COP (Conference of the Parties on United Nations Framework Convention on Climate Change) 15 was held in December, 2009, to construct the new protocol on reduction of $\mathrm{CO}_{2}$ emission following the Kyoto protocol which was valid until 2012.The new protocol is to form agreement of reduction of $\mathrm{CO}_{2}$ emission by 2020 in each country to avoiding the most serious consequences of climate change and determined to achieve the stabilization of atmospheric concentrations of global greenhouse gases considering and adopting the goal of achieving at least $50 \%$ reduction of global emissions by 2050. Negotiations in the COP continue in 2010.

Various considerations and measures to mitigate climate change are expected in various sectors such as energy supply, transport and its infrastructure, residential and commercial buildings, industry, agriculture, forestry and waste management. Enhancement of energy utilization efficiency is one of the key issues and adoption of renewable energy such as solar and wind energies are progressing in many countries. Among them, nuclear energy is an essential instrument of energy supply to mitigate global warming from the viewpoints of stable energy supply with necessary amounts, harmonization with global environment and 
economical competitiveness. The present status and perspective of electricity generation by nuclear power are discussed, covering that growing number of countries have recently expressed their interests in nuclear power programs as means to resolve climate change and energy security issues. Furthermore, nuclear energy can also produce high temperature gas to be used as process heat in chemical and petrochemical industries and production of hydrogen which can be used for steel making, fuel cell vehicles and so on. The Japan Atomic Energy Research Institute (JAERI, currently the Japan Atomic Energy Research and Development Agency (JAEA)) developed the HTGR technology capable of producing high temperature gas and succeeded in obtaining helium gas of $950^{\circ} \mathrm{C}$ at the reactor outlet in the HTTR through the development of various materials and introduction of new design concepts. On the other hand, the JAEA has took over from the JAERI development of a carbon free hydrogen production process in which the high temperature process heat can be provided by an HTGR. The process is high temperature thermo-chemical water splitting method using iodine and sulfur (IS process). So, nuclear energy can greatly contribute to build a low carbon society by providing electricity as well as process heat in various industries.

\section{Present status and perspective of energy consumption and $\mathrm{CO}_{2}$ emissions}

The total amount of energy consumption in the world is 11.4 billion tons of oil equivalents in the present time. The USA's share is $20 \%$, China's is $15 \%$, Russia's is $6 \%$, and India's is 5\%, etc. A projection of energy consumption by several regions for longer time span [2] was made by the Institute of International Association on System Analysis, IIASA-WEC as shown in Fig. 1. The total amount of energy consumption in the developing countries will exceed that in the developed countries in 2030, and will continue to increase dramatically. The total amount of energy consumption in 2100 will reach to 6.2 times of that in 2000 in the developing countries. This leads to an obvious question: are there so many energy resources in the earth?

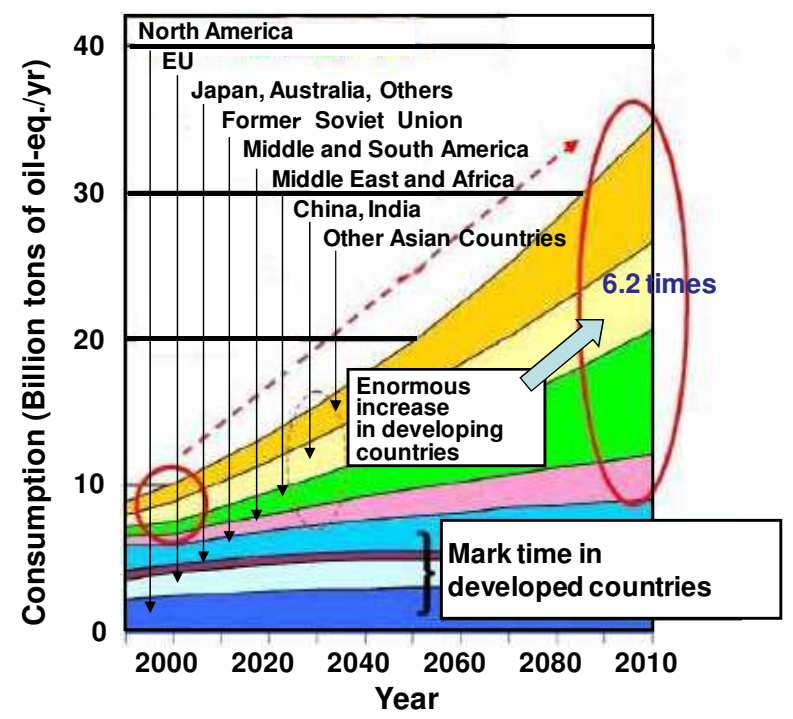

Fig. 1. History and perspective of world energy consumption by region 
As concerns share and amount of consumption of each energy resource, the OECD/IEA integrated the past results and projected future consumption of various energy sources from 1970 to 2030 as shown in Fig.2 [3]. The Agency estimated further increase of consumption of fossil fuels and that the total amount of energy consumption in 2030 will become 1.6 times higher than that in the present time. Furthermore, a great attention should be paid to the fact that fossil fuel holds over $80 \%$ of the total energy consumption. Are there inexhaustible fossil fuel resources?

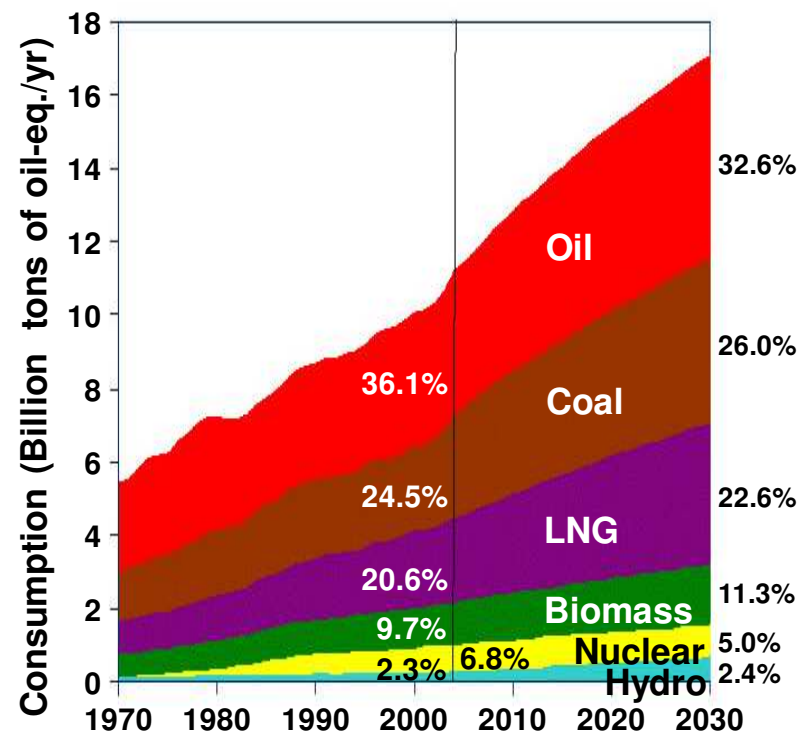

Fig. 2. History and perspective of world energy consumption by energy sources

The British Petroleum evaluated energy resource reserves and reserve-production ratio for fossil fuels [4] and IAEA and OECD/NEA projected them for uranium [5], as shown in Fig. 3. The reserve-production ratios of oil and natural gas are only 40 and 60 years, respectively. The definition of reserve-production ratio, here, is the reserve remaining at the end of year per production in that year. So, as far as new energy resources are not discovered and production is constant, the reserve-production ratio decreases 1 year for each energy source every year. If production in some year increases much more, the reserve-production ratio decreases much rapidly. As concerns uranium resources, the reserve is 5.47 million tons and the reserve-production ratio is more than 100 years. Furthermore, it becomes over 3000 years if a Fast Breeder Reactor (FBR) which produces more new plutonium fuel than spent plutonium becomes commercial. Namely, utilization efficiency of uranium resources reaches about $60 \%$ in the FBR cycle due to breeding plutonium fuel from uranium, recycling plutonium fuel and un-necessity of uranium enrichment with loss of uranium resources although it is about $0.5 \%$ in once-through use of uranium in a light water reactor. The reserve-production ratio sets here conservatively 30 times larger than that of oncethrough use case considering loss of recycling plutonium and uranium in the processes of re-processing of spent fuels and fuel fabrication. 
There is another subject to be discussed. The energy consumption per person in Canada and USA is around 8 tons of oil equivalent energy per year; that is 4.5 times higher than the global average. Most of European countries and Japan consume energy about a half of that of the former two countries per person. On the other hand, China and India consume one third and one eighth, respectively, of the European energy use per capita. It is thus reasonably expected that the developing countries will consume more energy than the present amount to facilitate continuous improvement in the standards of living to levels close to those of the developed countries.

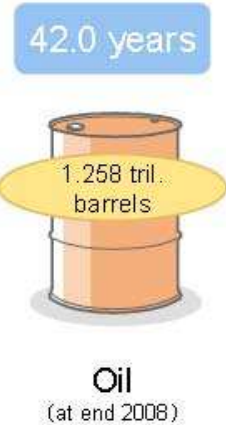

(at end 2008)

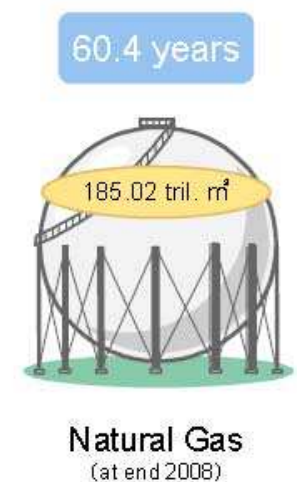

(atend 2008)

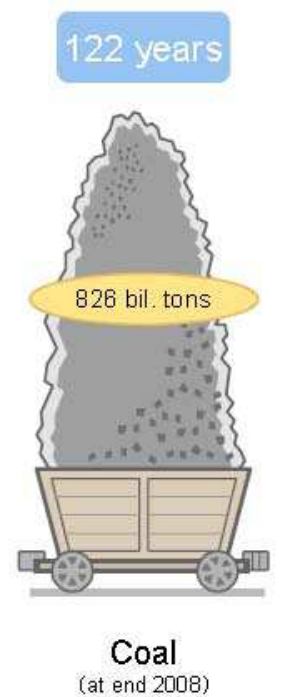

(at end 2008)

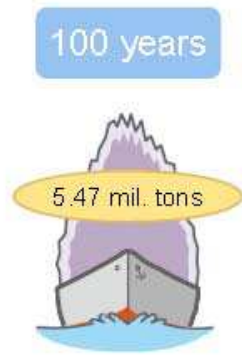

Uranium

(Jan. 2007)

Fig. 3. Proved reserves of energy resources

Global warming due to green house gases, especially carbon dioxide $\left(\mathrm{CO}_{2}\right)$ emission has become a serious issue. Carbon dioxide emissions by burning of fossil fuels scarcely occurred before the industrial revolution and atmospheric carbon dioxide concentration was stable at about $280 \mathrm{ppm}$. $\mathrm{CO}_{2}$ emissions have increased at first as the amount of coal consumption increased after the revolution, and then again after World War II together with oil consumption with industrial progress and economical expansion in developed countries. Recently, $\mathrm{CO}_{2}$ emissions due to burning of natural gas have been added. An increase of $\mathrm{CO}_{2}$ emissions in the last 35 40 years has been substantial and the total amount of $\mathrm{CO}_{2}$ emissions due to burning of fossil fuels reaches to about 26 billion tons. In accordance to this tendency, $\mathrm{CO}_{2}$ concentration in the atmosphere has increased to about $380 \mathrm{ppm}$ in the present time.

The IPCC reports that warming of the climate system is unequivocal, as is now evident from observations of increases in global average air and ocean temperatures, widespread melting of snow and ice, and rising global average sea level [1]. Anthropogenic warming over the last three decades has likely had a discernible influence on the global scale on observed changes in many physical and biological systems.

Several international organizations and institutes have projected $\mathrm{CO}_{2}$ emissions. Figure 4 shows $\mathrm{CO}_{2}$ emissions per year by countries in 2004 and estimated ones in 2030 by IEA [6]. The total $\mathrm{CO}_{2}$ emissions in the world per year will increase from 26 billion tons to more than 40 billion tons between 2004 and 2030, 1.6 times higher than the present $\mathrm{CO}_{2}$ emissions. 


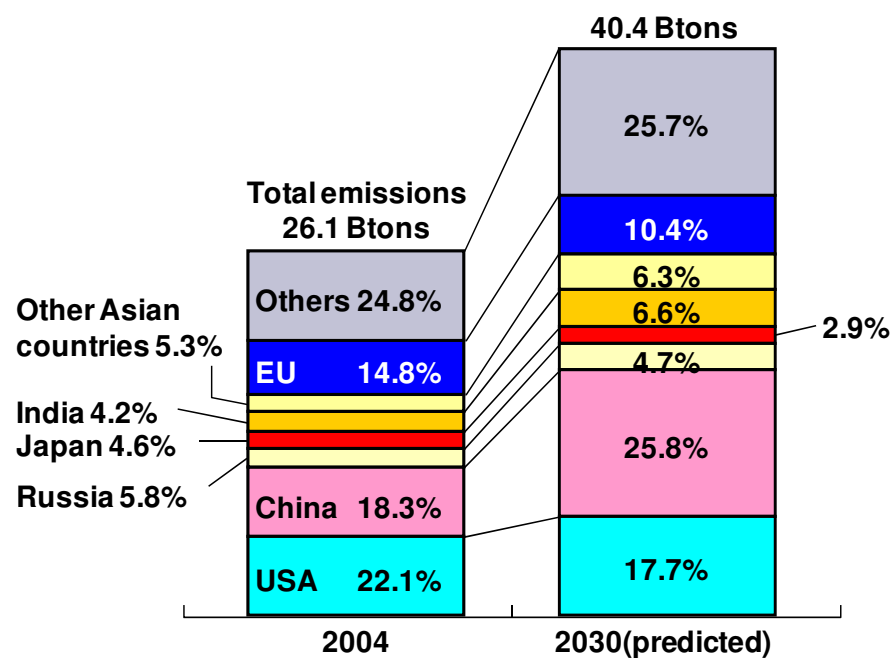

Fig. 4. Present stat1us and outlook of $\mathrm{CO}_{2}$ emissions/year by countries

Every country and region will emit more amount of $\mathrm{CO}_{2}$ per year. The IIASA estimated that $\mathrm{CO}_{2}$ emissions per year in 2100 would reach 3.5 times higher than those in 2000 [2], mostly due to increase of $\mathrm{CO}_{2}$ emissions in the developing countries as shown in Fig.5.

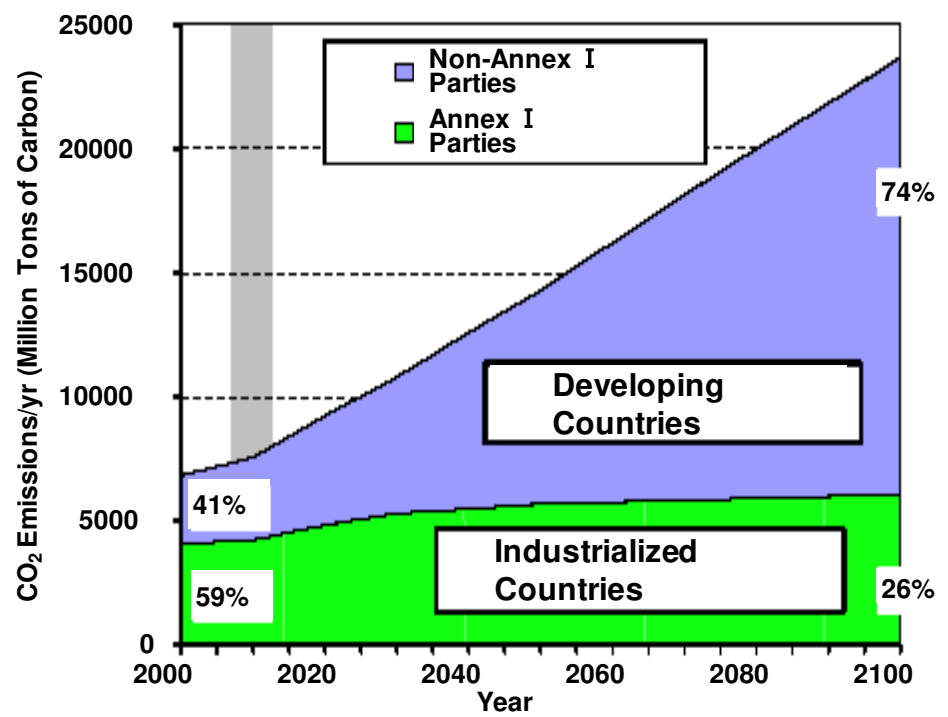

Fig. 5. Long range $\mathrm{CO}_{2}$ emission outlook

On the other hand, the IPCC suggested to maintain the temperature increase within $2{ }^{\circ} \mathrm{C}$ reducing $\mathrm{CO}_{2}$ emissions in 2050 by $50 \sim 85 \%$ of those in 2000 together with establishment of peaking year of $\mathrm{CO}_{2}$ emissions by 2015 in order to achieve less impact on global physical and biological systems. 


\section{Countermeasures against global warming and contribution of renewable energy to a low carbon society}

It can be recognized that there are several subjects to be resolved in order to construct a low carbon society under the present situation and projection of energy consumption, strong dependence on fossil fuels resulting in increasing emission of $\mathrm{CO}_{2}$ in future.

Several countermeasures against global warming are considered as follows.

- to increase energy efficiencies in various industries fields, and to save energy consumption, switching off the unnecessary lights and house-hold apparatus, changing the setting temperature of air- conditioners, etc.

- to introduce hybrid cars and electric vehicles instead of gasoline and diesel driven vehicles and to promote modal-shift.

- $\quad$ to introduce renewable energies and nuclear energy instead of fossil fuels.

- to develop and introduce carbon capture and storage system, if it is technically feasible and cost effective.

And, so on.

The introduction and limits of renewable energy and possibility of introduction of carbon capture and storage system are described in the chapter. The contribution of nuclear energy is analyzed and proposed in the next chapter.

Renewable energy is energy which comes from natural resources such as sunlight, wind, rain, tides, and geothermal heat, which are renewable (naturally replenished). Biomass and biofuels are also generally categorized as renewable energy because plants absorb carbon during growing up although they emit carbon during being used.

Renewable energy accounts for around $13 \%$ of primary energy supply of which $90 \%$ is traditional biomass for cooking and heating in developing countries in 2007 [8]. Biofuels contribute less than $2 \%$ of total transport liquid fuel supply.

Hydropower accounts for $16 \%$ of world electricity, and wind, solar and biomass together account for another $2 \%$ of electricity supply. As concerns hydropower, large scale hydroelectricity systems have been already mostly developed, therefore, only a small hydro system is discussed to be as new renewable energy.

A massive investment of over 100 billion US\$ has been made for development of technologies and installation of various renewable energies together with large subsidy to install them by the governments in the world. As the result, wind power is growing at the rate of $30 \%$ annually, with a worldwide installed capacity of $121 \mathrm{GW}$, solar photovoltaic power reaches $13 \mathrm{GW}$ in 2009 as shown in Table 1. Figure 6 shows installed capacities of solar photovoltaic power (PV) and wind power by countries as of March, 2009. As concerns PV, Germany, Spain and Japan are big three countries, and as for wind power USA, Germany and Spain are top three countries. Amounts of introduction of the abovementioned power quite depend on various political decisions by the government such as subsidy for installation and purchase of generated electricity by them in every country. A share of the total renewable energy power capacity becomes $6 \%$ of the total electricity power capacity from Table 1, however, it should pay attention that contribution of renewable energy to total electricity generation is only a few percent because capacity factors of wind power, PV, etc. are 10 to $20 \%$, although these are 80 to $90 \%$ in fossil fueled power and nuclear power, in general.

The utilization of renewable energy should be promoted together with technological innovation to bear a part of construction of a low carbon society from view points of not 
only reduction of $\mathrm{CO}_{2}$ emitted by burning of fossil fuels but also fear of shortage of fossil fuel resources. Table 2 summarizes general evaluation result of various energy resources.

\begin{tabular}{|l|c|}
\hline \multicolumn{1}{|c|}{ Technology } & Electric Power Capacity (GW) \\
\hline Wind power & 121 \\
\hline Small hydropower & 85 \\
\hline Biomass power & 52 \\
\hline Solar photovoltaic power & 13 \\
\hline Geothermal power & 10 \\
\hline Solar termal power & 0,5 \\
\hline Tidel power & 0,3 \\
\hline Total renewable power & 280 \\
\hline Total electric power capacity & 4,700 \\
\hline
\end{tabular}

Table 1. Renewable electric power capacity

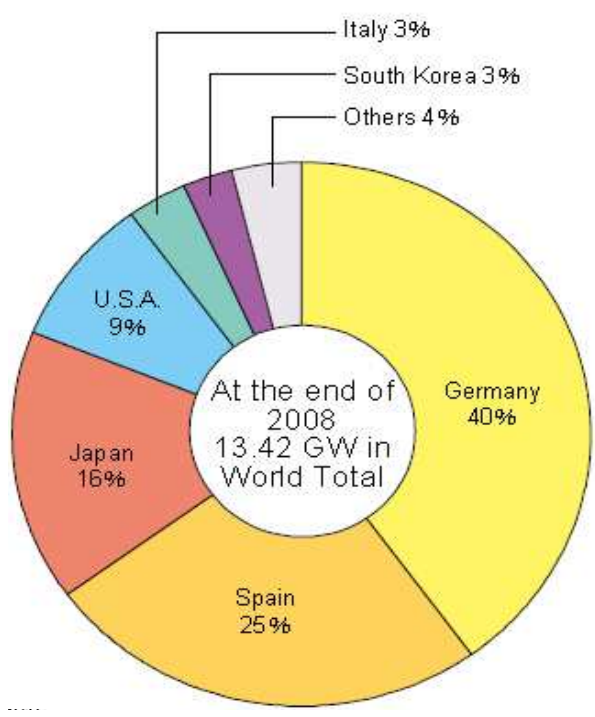

(a) Solar photovoltaic power

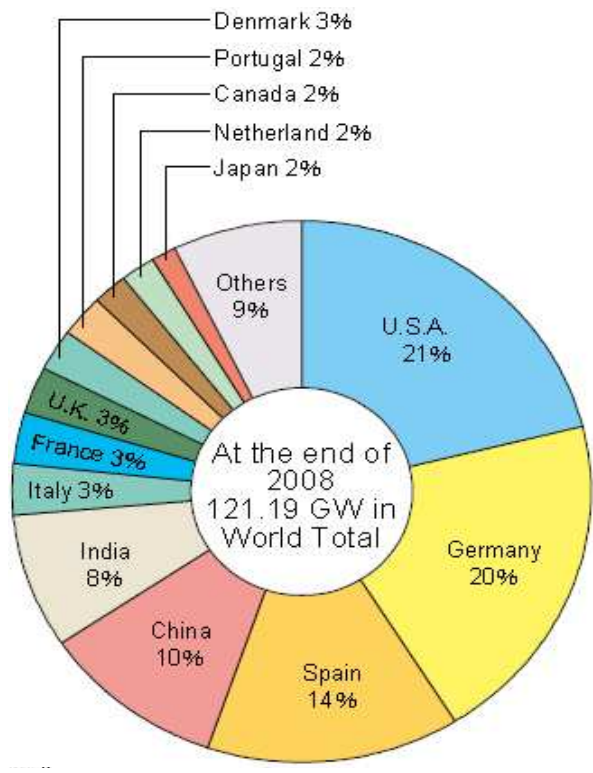

(b) Wind power

Fig. 6. Photovoltaic power and wind power generation capacities in the world

Many countries have introduced wind power and solar energy, however, amounts of electricity generation by them is small in general and unstable. Furthermore, energy intensity of them is very low, then, huge space is needed to achieve some amounts of electricity generation by them. Therefore, electricity generation cost is very high, especially in PV, then, the governments have offered large amounts of subsidy for installation of them which comes from tax paid by people. Smart grid which connects PV and/or wind power with battery, in some case battery installed in electric vehicles is discussed and developing currently. It might be an idea to improve to use wind power and solar energy effectively and more cost-efficiently. On the other hand, there is some optimistic estimation that the 
long-term technical potential of wind energy will be five times total current global energy production, or 40 times current electricity demand. This could require large amounts of land to be used for wind turbines, particularly in areas of higher wind resources. Offshore resources experience mean wind speeds of $\sim 90 \%$ greater than that of land, so offshore resources could contribute substantially more energy although it is not applicable to every country. As concerns PV, building-integrated photovoltaics or "onsite" PV systems have the advantage of being matched to end use energy needs in terms of scale. So the energy is supplied close to where it is needed.

\begin{tabular}{|c|c|c|c|c|}
\hline & Wind power & Solar photovoltaic & Geothermal energy & Biomass \\
\hline $\begin{array}{l}\text { Resource } \\
\text { (or scale) }\end{array}$ & $\triangle$ & $\triangle$ & $\triangle$ & $\triangle$ \\
\hline Cost & $\triangle$ & $x$ & $\triangle$ & $\triangle$ \\
\hline No $\mathrm{CO}_{2}$ emission & (2) & (?) & (0) & (-) \\
\hline Public acceptance & (?) & (0) & $\triangle$ & (2) \\
\hline $\begin{array}{l}\text { Subjects to be solved or } \\
\text { difficulties }\end{array}$ & $\begin{array}{l}\text { Cost and limitation of } \\
\text { introduction }\end{array}$ & $\begin{array}{l}\text { Cost and limitation of } \\
\text { introduction }\end{array}$ & Limitation of resource & Limitation of resource \\
\hline Solution & $\begin{array}{l}\text { Dispersal use, smart } \\
\text { grid }\end{array}$ & $\begin{array}{l}\text { Innovative technology, } \\
\text { dispersal use, smart } \\
\text { grid }\end{array}$ & Innovative technology & Innovative technology \\
\hline & Biofuel & Oil & Coal & Nuclear \\
\hline Resource (or scale) & $\triangle$ & $\triangle$ & 0 & $\mathrm{O}$ \\
\hline Cost & $\triangle$ & $\triangle$ & $\mathrm{O}$ & (2) \\
\hline No $\mathrm{CO}_{2}$ emission & (2) & $x$ & $x$ & (?) \\
\hline Public acceptance & $\mathrm{O}$ & O & $\mathrm{O}$ & $\Delta$ \\
\hline $\begin{array}{l}\text { Subjects to be solved or } \\
\text { difficulties }\end{array}$ & $\begin{array}{l}\text { Production from other } \\
\text { plants than sugar } \\
\text { cane, corn }\end{array}$ & Limitation of resource & $\begin{array}{l}\text { Gasification } \\
\text { technology, } \\
\text { Carbon capture and } \\
\text { storage technology }\end{array}$ & $\begin{array}{l}\text { Public acceptance, } \\
\text { radioactive waste } \\
\text { disposal }\end{array}$ \\
\hline Solution & Innovative technology & $\begin{array}{l}\text { Increase utilization } \\
\text { efficiency }\end{array}$ & Innovative technology & $\begin{array}{l}\text { Communication with } \\
\text { public }\end{array}$ \\
\hline
\end{tabular}

Table 2. General evaluation result of various energy resources

According to the BLUE Map scenario by IEA, in which $\mathrm{CO}_{2}$ emissions are halved by 2050, biomass would become by far the most important renewable energy source. Its use would increase nearly four-fold by 2050, accounting for around $23 \%$ of total world primary energy. Such a level of use would require approximately 15,000 Mt of biomass to be delivered to processing plants annually. Around half of this would come from crop and forest residues, with the remainder from purpose-grown energy crops. The scenario seems to be very hardly possible.

Another recent attention and controversy have focused on biofuels, which have been growing at a rapid rate. Some of the current "first generation" biofuels (derived from grains and oil-seed crops) raise questions of sustainability, as they compete with food production 
and contribute to environmental degradation, with dubious $\mathrm{CO}_{2}$ benefits. However, introduction of "second generation" biofuels, e.g. from grasses, trees and biomass wastes, should help overcome most problems and provide sustainable fuels with large GHG reductions. Major deployment of second generation biofuels should be replaced with first generation biofuels.

Apart renewable energies, carbon capture and storage (CCS) is a means of mitigating $\mathrm{CO}_{2}$ emission based on capturing $\mathrm{CO}_{2}$ from large point sources such as fossil fuel power plants, and storing it away from the atmosphere by different means. CCS will bring great contribution to reduction of $\mathrm{CO}_{2}$ emission to the atmosphere, if it becomes technically and economically feasible. However, there are many technical subjects to be solved in the process of capturing $\mathrm{CO}_{2}$, transportation of $\mathrm{CO}_{2}$ by pipe line, injection of $\mathrm{CO}_{2}$ into storage site together with its safety and public acceptance. As concerns $\mathrm{CO}_{2}$ capture from the point source, broadly, three different types of technologies exist: post-combustion, precombustion, and oxyfuel combustion. In the post-combustion capture, the technology is well understood and is currently used in other industrial applications, although not at the same scale as might be required in a commercial scale power station. A few engineering proposals have been made for the more difficult task of capturing $\mathrm{CO}_{2}$ directly from the air, but work in this area is still in its infancy.

Storage of the $\mathrm{CO}_{2}$ is envisaged either in deep geological formations, in deep ocean masses, or in the form of mineral carbonates [9]. In the case of deep ocean storage, there is a risk of greatly increasing the problem of ocean acidification, a problem that also stems from the excess of carbon dioxide already in the atmosphere and oceans. Geological formations are currently considered the most promising sequestration sites although there are not so many appropriate sites. Purpose-built plants near a storage location are recommended and applying the technology to preexisting plants or plants far from a storage location will be more expensive. Safety issue of CCS is leakage of $\mathrm{CO}_{2}$ from transportation piping system and storage location. In fact, a large leakage of naturally sequestered carbon dioxide rose from Lake Nyos in Cameroon and asphyxiated 1,700 people in 1986.

CCS applied to a modern conventional power plant could reduce $\mathrm{CO}_{2}$ emissions to the atmosphere by approximately $80 \sim 90 \%$ compared to a plant without CCS. The IPCC estimates that the economic potential of CCS could be between $10 \%$ and $55 \%$ of the total carbon mitigation effort until year 2100, considering Capturing and compressing $\mathrm{CO}_{2}$ requires much energy and would increase the fuel needs of a coal-fired plant with CCS by $25 \% \sim 40 \%$.

Micro hydro systems are hydroelectric power installations that typically produce up to 100 $\mathrm{kW}$ of power. They are often used in water rich areas as a remote-area power supply. There are many of these installations around the world, which are also renewable energy.

\section{Current and future role of nuclear energy}

\subsection{Electricity generation}

Although nuclear energy has a misfortune and tragic history to be used first as nuclear bomb, peaceful use of nuclear energy was initiated and has been promoted based on the speech of "Atoms for Peace" by USA President Eisenhower at United Nations in 1953. Many developed countries started and promoted the construction of nuclear power plants mostly due to oil crises and energy security. However, the pace of construction of nuclear power plants became stagnant in several countries after Three Mile Island (TMI) and Chernobyl 
accidents. Currently, 432 nuclear power plants are operating world-wide, producing $16 \%$ of the total electricity generation, or $6 \%$ of all primary energy production with total plant capacity of 390 GWe [10] as shown in Fig.7. USA has a quarter of the total producing $20 \%$ of the total electricity generation in the country, nuclear power produces about $80 \%$ of the total electricity generation which reaches to truly $43 \%$ of primary energy production in France and one third of the total, or $14 \%$ of all primary energy production in Japan.

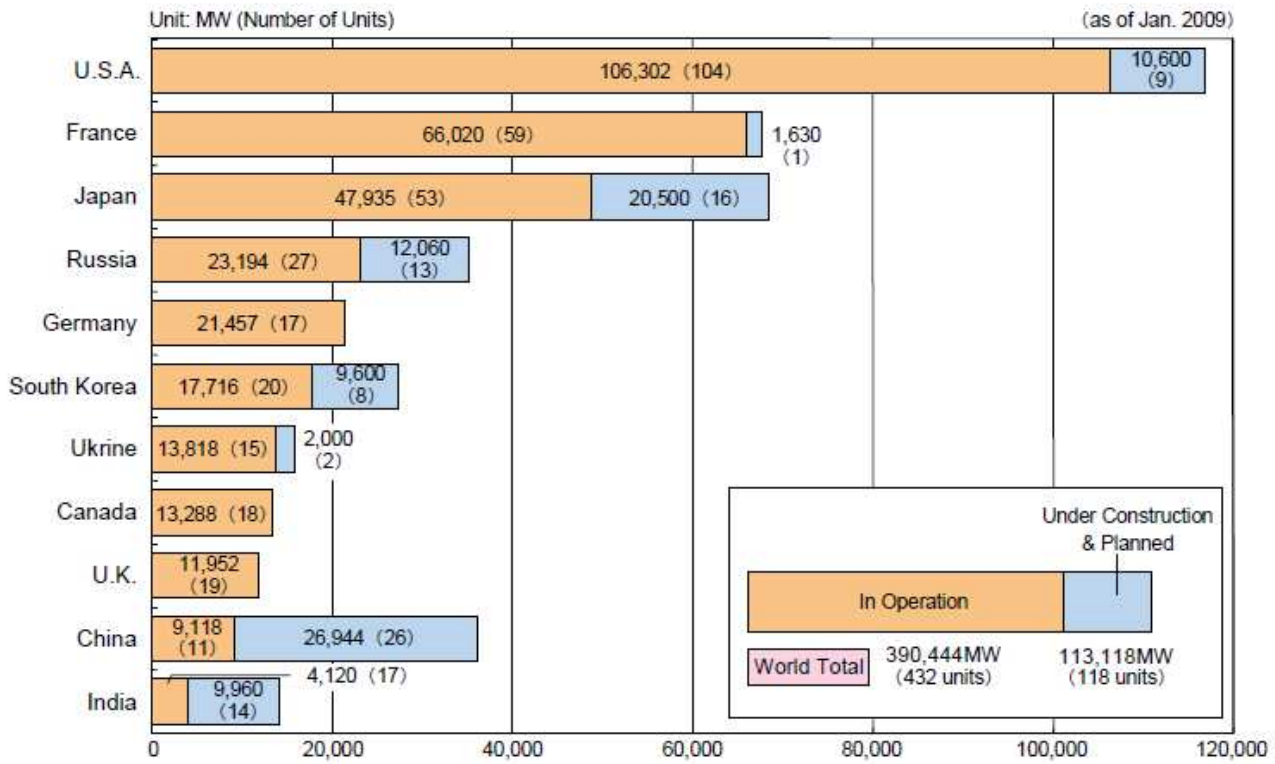

Fig. 7. Generated capacity of nuclear power plants in major countries

As described in the G8 Summit leaders declaration, a growing number of countries currently regard nuclear power as an essential instrument in reducing dependence on fossil fuels, and hence greenhouse gas emissions. Fig.8 shows amount of $\mathrm{CO}_{2}$ emissions through life cycle of each electricity energy source in unit of $\mathrm{g}-\mathrm{CO}_{2}$ per $\mathrm{kWeh}$ [11]. Clearly, fossil fuel fired power plants emit enormous amounts of $\mathrm{CO}_{2}$ from about $500 \mathrm{~g} \sim 1 \mathrm{~kg} / \mathrm{kWeh}$ compared with renewable energies and nuclear power which emit $\mathrm{CO}_{2}$ only from 10 to $50 \mathrm{~g} / \mathrm{kWeh}$. In fact, amount of $\mathrm{CO}_{2}$ emission by nuclear power is $1 / 25 \sim 1 / 45$ of that by fossil fuel. If the existing nuclear power plants are replaced with oil and coal fired power plants, for example, amount of $\mathrm{CO}_{2}$ emissions would increase by 230 million tons, which is equivalent to about $20 \%$ of the total $\mathrm{CO}_{2}$ emissions in Japan. Furthermore, nuclear power is the cheapest electricity source at least in Japan and in a similar situation internationally as shown in Fig.9. A number of countries have recently expressed their interests in nuclear power programs as means to addressing climate change and energy security concerns based on the situation described above, so it is said that we are entering a "Nuclear Renaissance". In fact, USA is going to re-start construction of new nuclear power plants after the TMI accident, France and Japan are steadily constructing new nuclear plants. Russia, China and India have big plans to build 13 26 new nuclear plants by 2020 or 2030, and several plants are being constructed already as added in Fig.7. A plant unit capacity of them is 1000 1600MWe 
mostly. Many other countries in Asia, Middle East, Africa and South America are considering introduction of nuclear power. According to the latest data as of March, 2010 [12], 55 nuclear power plants are under construction in the world with an installed capacity of $51 \mathrm{GWe}$, equivalent to $14 \%$ of present capacity, in 15 countries including 21 plants in China, 8 in Russia, 6 in Republic of Korea, and 5 in India. In addition, WNA (World Nuclear Association) reported in April, 2010 that 195 new nuclear power plants will be constructed by 2020 and another 344 nuclear plants will follow by 2025 in the world, including 156 plants in China, 54 plants in India and 46 plants in Russia [13].

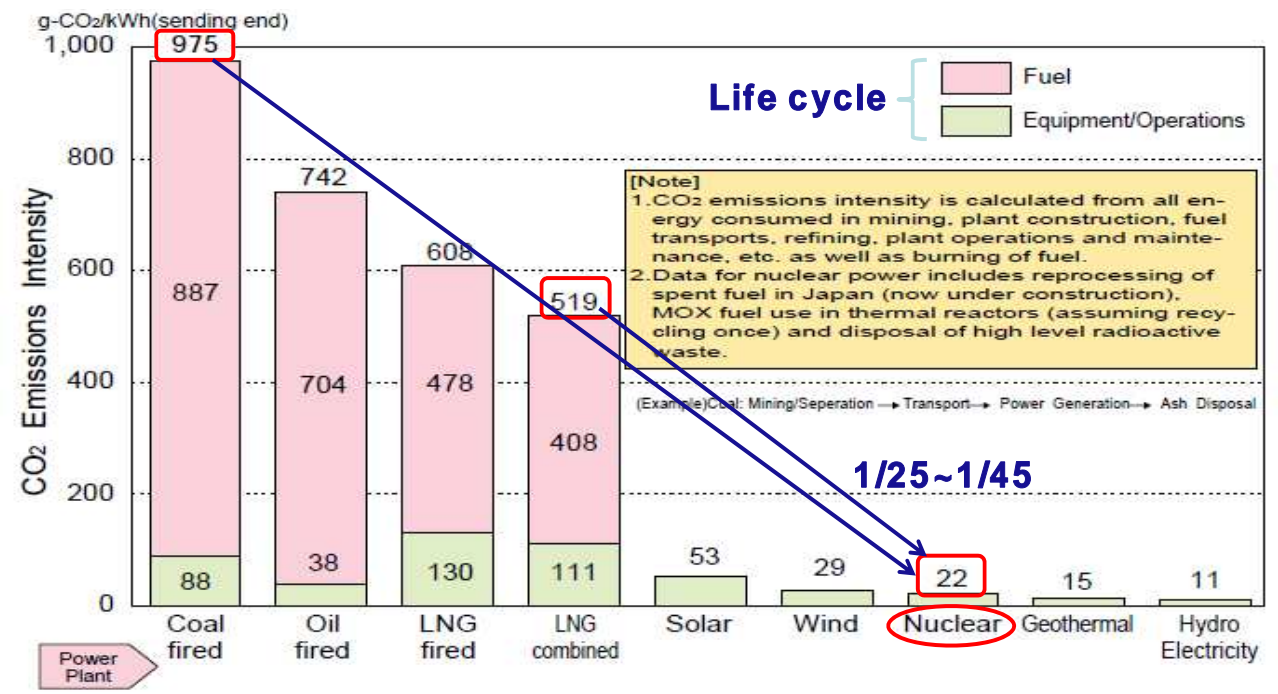

Fig. 8. $\mathrm{CO}_{2}$ Emissions Intensity by electric source

On the other hand, an increase of world-wide energy consumption in 2030 is projected to be $60 \%$ over the present level. In order to maintain the current level contribution of nuclear power of $16 \%$ to the total electricity generation in the world, another 250 GWe nuclear power is needed by 2030 under the assumption of the same ratio of electric power contribution to the total energy consumption, besides replacing retired nuclear plants with new ones meantime. The current contribution of nuclear power to the reduction of $\mathrm{CO}_{2}$ emissions is about $9 \%$ in the world. If we wish to raise this figure to $20 \%$ in 2030, new nuclear power plants with about 700 GWe are needed by 2030, that is, construction of 700 nuclear power plants with a capacity of $1000 \mathrm{MWe}$ in the world. These are summarized in Table 3.

\subsection{Nuclear heat utilization in various industries}

Another type of nuclear energy system has a great possibility to contribute to create a low carbon future society together with current nuclear power system. That is a high temperature gas-cooled reactor, HTGR, which can produce helium gas of about $1000{ }^{\circ}$ Cat the reactor outlet. If so high temperature gas can be obtained, fields of nuclear energy utilization are surely widen in not only electricity generation but also hydrogen production, direct steel making by deoxidization of iron ore, process heat in various chemical and 
petrochemical industries, and so on, as shown in Fig.10. That means also to contribute as countermeasure against shortage of oil, coal and natural gas. Currently, only two HTGR test reactors, namely, HTTR in Japan and HTR-10 in China, are operating in the world. The HTR-10 is a very small reactor and helium gas temperature at the reactor outlet is $700^{\circ} \mathrm{C}$. Furthermore, the technology of high temperature thermo-chemical decomposition of water utilizing iodine and sulfur has most progressed in the JAEA in the world. Therefore, the most advanced technologies in these fields in the JAEA are described here.

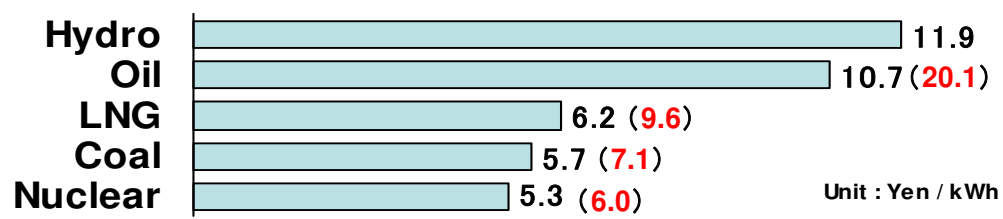

Japanese Case (black letter : based on fuel price on 2002, by METI ;
red letter : based on fuel price on Feb., 2008, by FEPC)

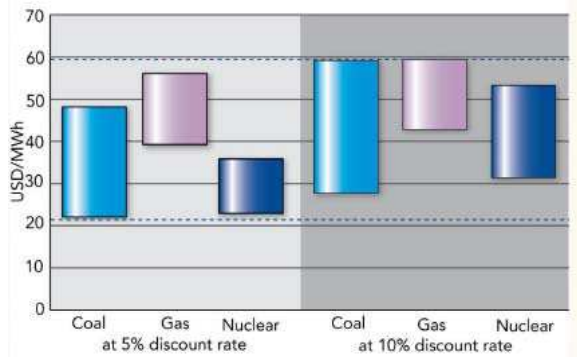

\section{Range of Levelised Costs ( OECD/NEA \\ Nuclear Energy Outlook 2008)}

Fig. 9. Comparison of electricity generation cost

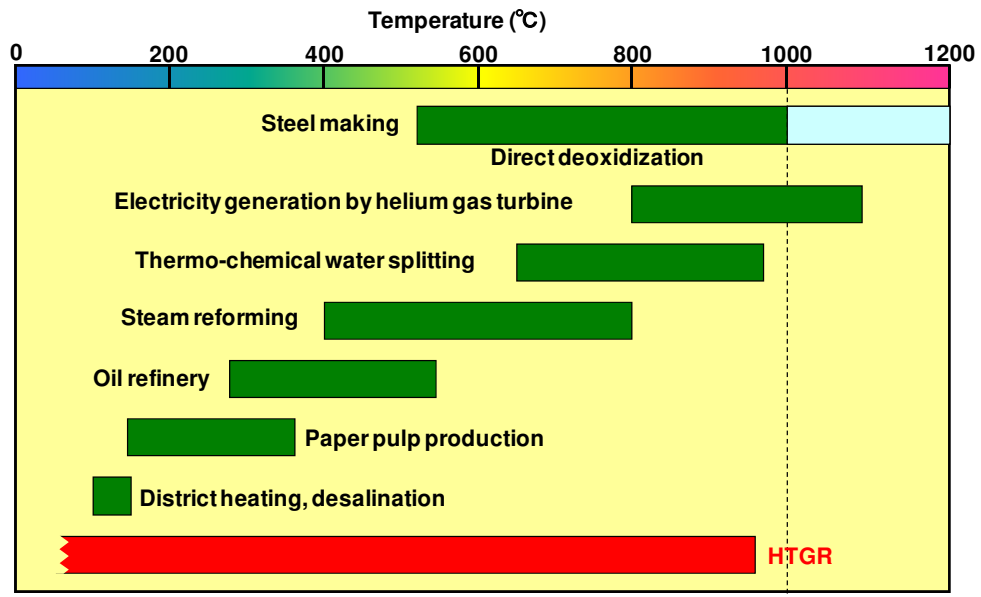

Fig. 10. Process heat temperature ranges used in various industries 
The JAERI developed the HTTR [14], a 30 MWt HTGR test reactor, and succeeded in getting helium gas of $950{ }^{\circ} \mathrm{C}$ at reactor outlet of the HTTR in 2004 for the first time in the world. Several key technologies are described below. One of big differences between an LWR and an HTGR is that no metal is used in the reactor core of the HTGR. The fuel element of HTTR, for example, is quite different from that of LWR as shown in Fig.11. In the
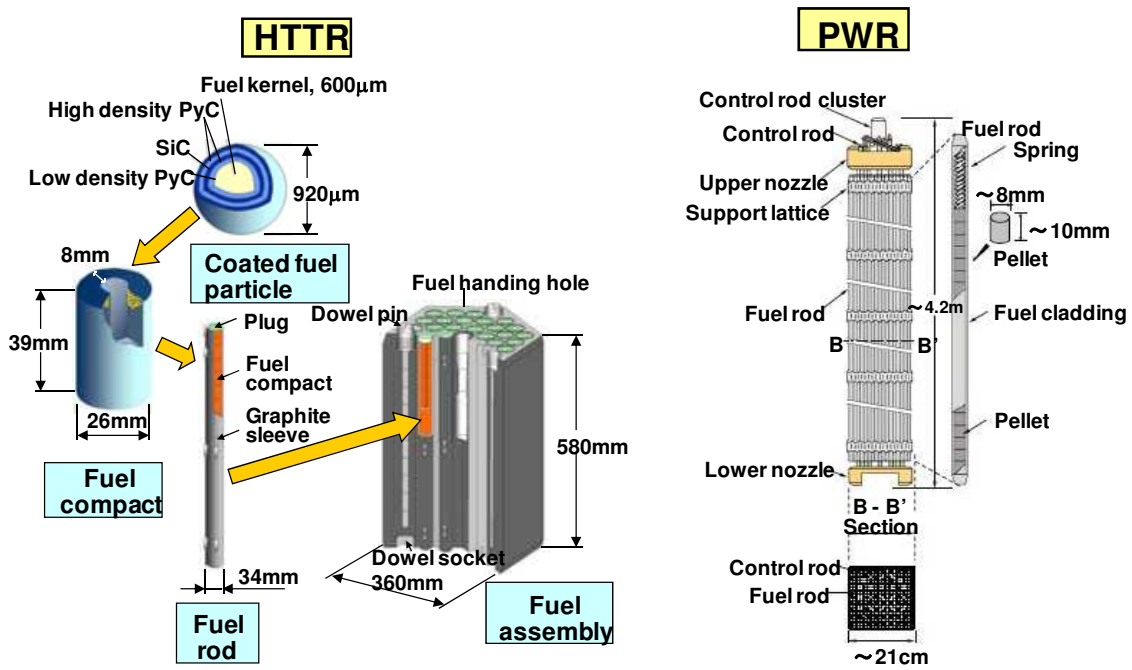

Fig. 11. Details of fuel structure of HTTR and LWR

HTTR, coated fuel particles consisted of low enriched $\mathrm{UO}_{2}$ kernel with TRISO coating are combined with graphite powder to form a fuel compact which is equivalent to $\mathrm{UO}_{2}$ pellet in LWR. A fuel rod is composed of graphite sleeve in which fuel compacts are contained. A fuel assembly is a pin-in-block type hexagonal fuel element, that is, helium gas flows through the gap between a vertical hole and a fuel rod to remove the heat produced by fission and gamma heating. Excellent graphite for core and its surrounding components which has less dimensional change due to neutron irradiation, large tensile strength and high corrosion resistance is needed. The JAERI succeeded in development of IG-110 which satisfies the above-mentioned requirements as shown in Fig. 12. As concerns the coated fuel particle, great efforts had been made to improve fabrication technologies having made neutron irradiation tests resulting in production of very high quality one. As for heat resistant alloy for piping systems, Ni-base Hastelloy XR with very high corrosion resistance had been finally developed.

Also, the JAEA has been developing operation technologies of HTGR by using the HTTR so as to supply high temperature heat stably to heat utilization systems, and succeeded in continuous operation for 50-days at high-temperature of about $950{ }^{\circ} \mathrm{C}$ in 2010 , which was the first demonstration making stable nuclear heat supply possible. Due to the successful long-term operation, nuclear heat utilization with the HTGR became realistic. One of the promising nuclear heat utilization is a large amount of hydrogen production aiming for reduction of $\mathrm{CO}_{2}$ emission, because hydrogen is said to be a most promising energy carrier for low carbon society. However, if it is produced by utilizing fossil fuels as it was, such as in steam reforming process with $\mathrm{CO}_{2}$ emissions, hydrogen is not really clean energy. 


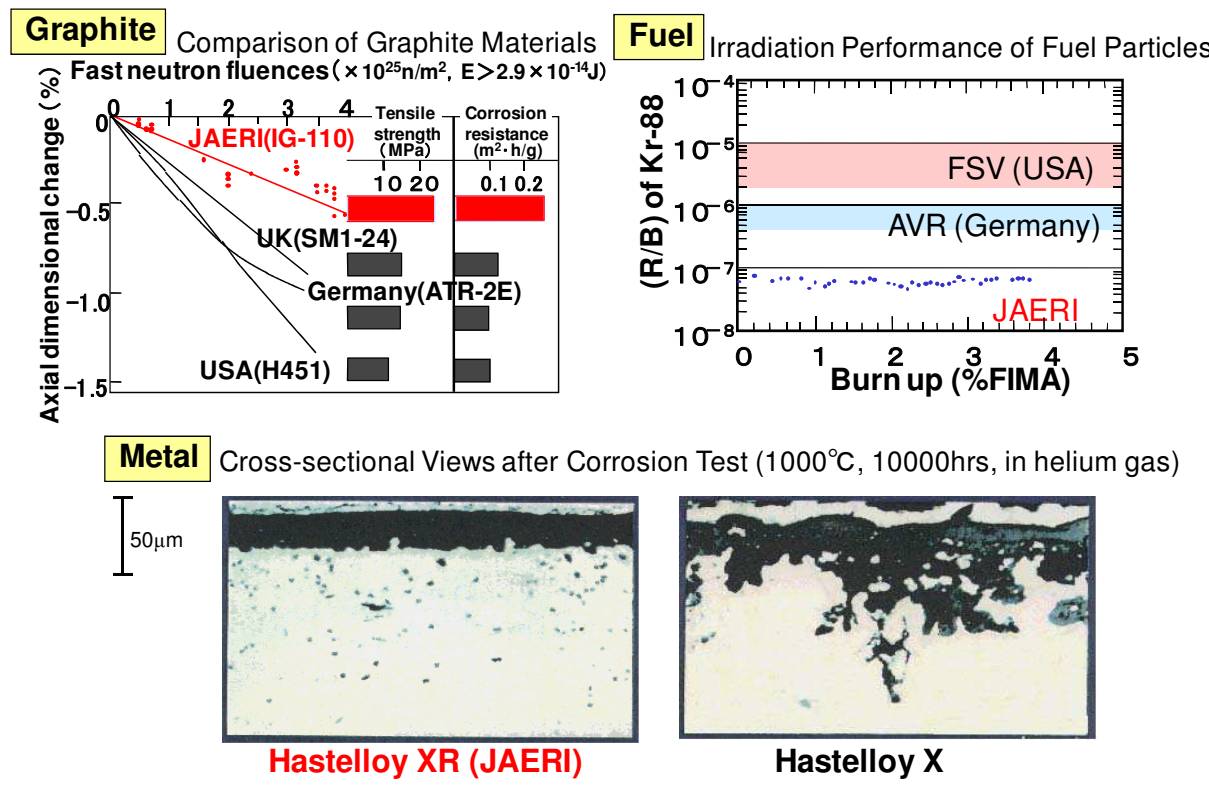

Fig. 12. Several results of research and development for HTTR

Therefore, the JAEA has devoted substantial resources to develop a high temperature thermo-chemical decomposition of water utilizing iodine (I) and sulfur (S), the IS process as shown in Fig. 13 and successfully achieved continuous hydrogen production [15] and [16]. In this process, high temperature process heat is used in sulfuric acid and iodine hydride decomposition reactions. Iodine and sulfur are used cyclically, water is alone the feedstock to produce hydrogen and oxygen. The IS process coupled with HTGR (HTGR-IS), is a really clean hydrogen production system and economically competitive to those of steam reforming of methane and coal and superior to that of water electrolysis [17]. In fact, Ewan and Allen evaluated hydrogen cost for various production routes considered [18].

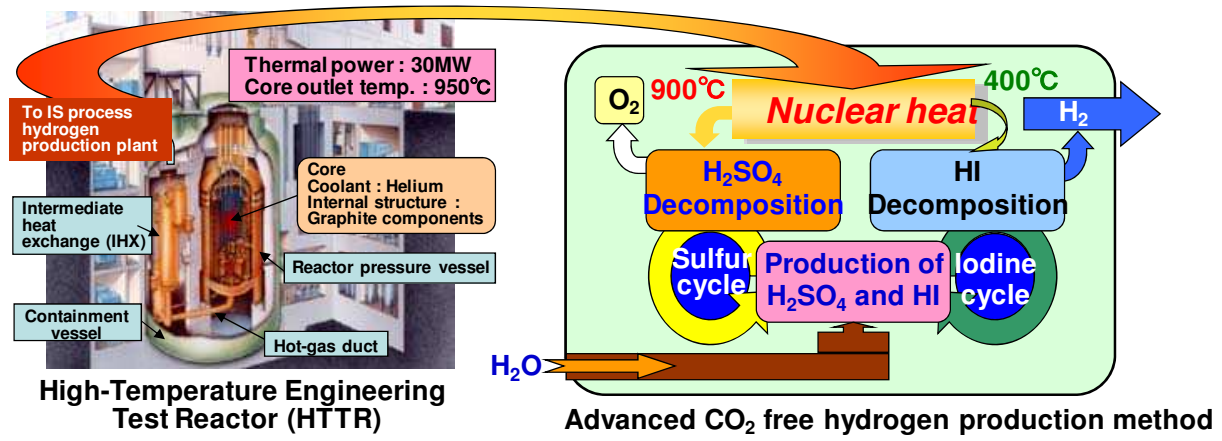

Fig. 13. Nuclear heat application from HTGR to IS-hydrogen production

According to their report, hydrogen production costs per ton are 982 US\$ for steam reforming of methane (SMR), 1575 US\$ for SMR + carbon capture, 1270 US\$ for 
nuclear/thermocycle, 1621 US\$ for coal, 3114 US\$ for coal + carbon capture, 4725 US\$ for hydroelectric, 14,950 US\$ for solar PV, etc. On the other hand, several methods are recently proposed to produce hydrogen utilizing an HTGR and other types of reactors [19], [20], [21] and [22], however, IS method is considered to be the most progressed, promising and good cost performance one without emission of $\mathrm{CO}_{2}$ among them.

To apply nuclear energy by HTGR to extensive non-electricity fields, the JAEA proposed the original HTGR system, GTHTR300C as shown in Fig.14 [23]. The GTHTR300C is the first commercial-scale HTGR cogeneration plant with 600MWt combining electricity generation by a direct cycle gas turbine and hydrogen production by the thermochemical IS process.

The direct cycle gas turbine of a recuperated Brayton cycle generates electricity and circulates reactor coolant, performing both tasks most efficiently relative to all other forms of process arrangement. Hydrogen cogeneration is enabled by adding an intermediate heat exchanger (IHX) in serial between the reactor and the gas turbine. A secondary loop delivers hot helium gas from the IHX to the IS process hydrogen plant over a sufficient distance that together with the isolation valves located in the secondary loop circuits provides safe and environmental separation between the nuclear plant and the conventional-grade hydrogen plant [24].

Additionally, the seawater desalination plant can be provided readily as a cooling system of removing the sensible waste heat of the Brayton cycle gas turbine power conversion and without an efficiency penalty to either the power generation or high temperature process heat utilization. Providing a seawater desalination plant making freshwater as shown in Fig.14, the HTGR system has an exceedingly high thermal efficiency up to $80 \%$, which is called an "HTGR cascade energy plant" utilizing heat in a cascade manner from high

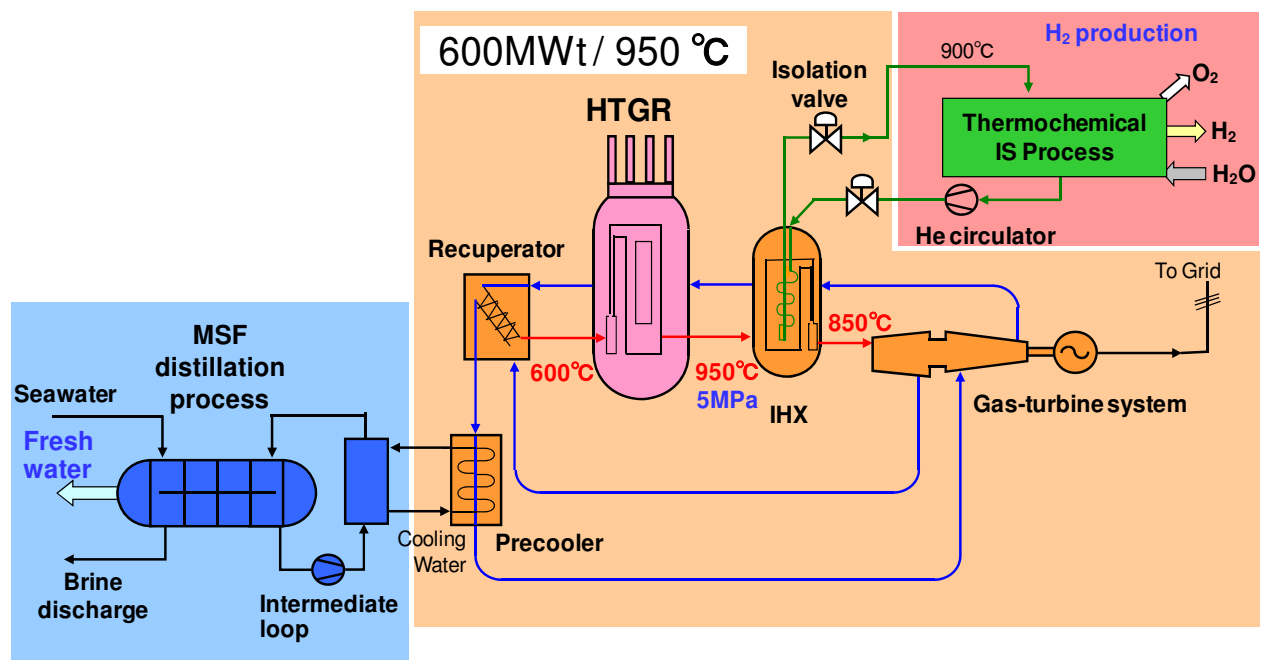

Fig. 14. HTGR cascade energy plant for $80 \%$ efficient production of hydrogen, electricity and freshwater

temperature to low temperature, for example, although thermal efficiency of a current light water reactor (LWR) is $34 \%$. Due to this high thermal efficiency, the HTGR system can operate by using a small cooling system, whose cooling water consumption is reduced to less than 
one-third of what the existing LWR needs. For the same reason that the desalination can be completely driven by the high temperature $\left(160^{\circ} \mathrm{C}\right)$ exhaust heat of the gas turbine. On the other hand, the HTGR power and heat cogeneration plant can be operated by using economical air cooler, excluding any need for a cooling water source near the plant site due to exhaust heat is rather small compared to conventional power plants and light water reactors. These environmentally friendly characteristics make the HTGR uniquely suited to barren inland provinces, and other regions, where cooling water resource is scarce.

The HTGR of $600 \mathrm{MWt}$ can produce a maximum of 300MWe electricity, 650 tonnes/hour of quality steam at $500^{\circ} \mathrm{C}$, and $85,000 \mathrm{~m}^{3}$ / hour of hydrogen, or it can simultaneously cogenerate fractions of all these products by the HTGR cascade plant said above and with the addition of a steam boiler in parallel with or in place of the hydrogen production plant.

Many industrial and market applications are possible for the energy and feedstock obtained from the HTGR. The steam and hydrogen products can be used to refine and hydrogenate profitable clean petroleum products from the crude oils. The steam can be used to reform coal to produce synthetic gas and transportation liquid fuel. The hydrogen produced from a 600MWt HTGR is sufficient to provide fuel to more than half a million of fuel cell vehicles and eliminate 1.45 million tonnes of $\mathrm{CO}_{2}$ emission by replacing the same number of gasoline cars. New and environmentally friendly industries can be created. As an example, in the current steel making process, huge amount of coke produced from coal is used for the reduction of iron ore with a significant $\mathrm{CO}_{2}$ emission $\left(\mathrm{Fe}_{2} \mathrm{O}_{3}+\mathrm{CO}->2 \mathrm{Fe}+3 \mathrm{CO}_{2}\right)$. In order to reduce the $\mathrm{CO}_{2}$ emission, the substitution of coke by hydrogen in the steel making is being studied in the Japanese 'Course $50^{\prime}$ plan. The direct steel making using hydrogen $\left(\mathrm{Fe}_{2} \mathrm{O}_{3}+\right.$ $3 \mathrm{H}_{2}->2 \mathrm{Fe}+3 \mathrm{H}_{2} \mathrm{O}$ ) by a $600 \mathrm{MWt}-\mathrm{HTGR}$ for hydrogen supply can produce over half a million tonnes of steels while reducing $\mathrm{CO}_{2}$ emission by 1.24 million tonnes per year, compared with the current steel making process using coke.

A preliminary evaluation on the reduction of $\mathrm{CO}_{2}$ emissions is made for the case in Japan [25]. A reduction of $\mathrm{CO}_{2}$ of 170 million tons (13\%) could be realized through the replacement of 50 million automobiles (2/3 of all cars in Japan) with fuel cell vehicles, 100 million tons $(8 \%)$ by the adoption of direct steel making utilizing hydrogen and 30 million tons $(2.3 \%)$ in the chemical and petrochemical industrial complexes by the adoption of process heat and electricity produced by the HTGR system, respectively. Namely, a total amount of $\mathrm{CO}_{2}$ reduction reaches to $23 \%$ of the total emission of 1.3 billion tons in Japan.

As for spent fuel treatment and disposal, coated particle fuels are very convenient to direct disposal because fuel kernel is coated by ceramics triply. Re-processing of spent fuels is also possible by the current Purex method. Technologies of the pretreatment consisting of, in the case of prismatic fuel elements, separation of fuel particles from fuel compact and the following extraction of fuel kernel from a coated fuel particle by crashing have already been performed for HTTR fuels in a laboratory scale [15]. Concerning the chemical waste of the HTGR+IS, it will not bring a special issue to be considered since the IS process constitutes a closed cycle in terms of the sulfur- and iodine-compounds, in principle.

Commercialization of HTGR and HTGR-IS system could be attained through demonstration of nuclear hydrogen production by the IS process connected with HTTR (HTTR-IS system) shown in Fig.15, and operation of a demonstration HTGR with about 30 MWt. Since the utilization system of high temperature heat obtained by an HTGR can be flexibly designed based on user's needs, HTGR technology can widely applied to the nonelectricity fields, so that, it would be expected to dramatically reduce global $\mathrm{CO}_{2}$ emissions. 
Primary energy of about $60 \%$ is consumed in non-electricity fields in the world. Hence, the worldwide deployment of the HTGR system, i.e., clean and high efficiency nuclear energy, in the near future is expected to reduce huge amount of the $\mathrm{CO}_{2}$ emission, which can contribute to build a low carbon society.

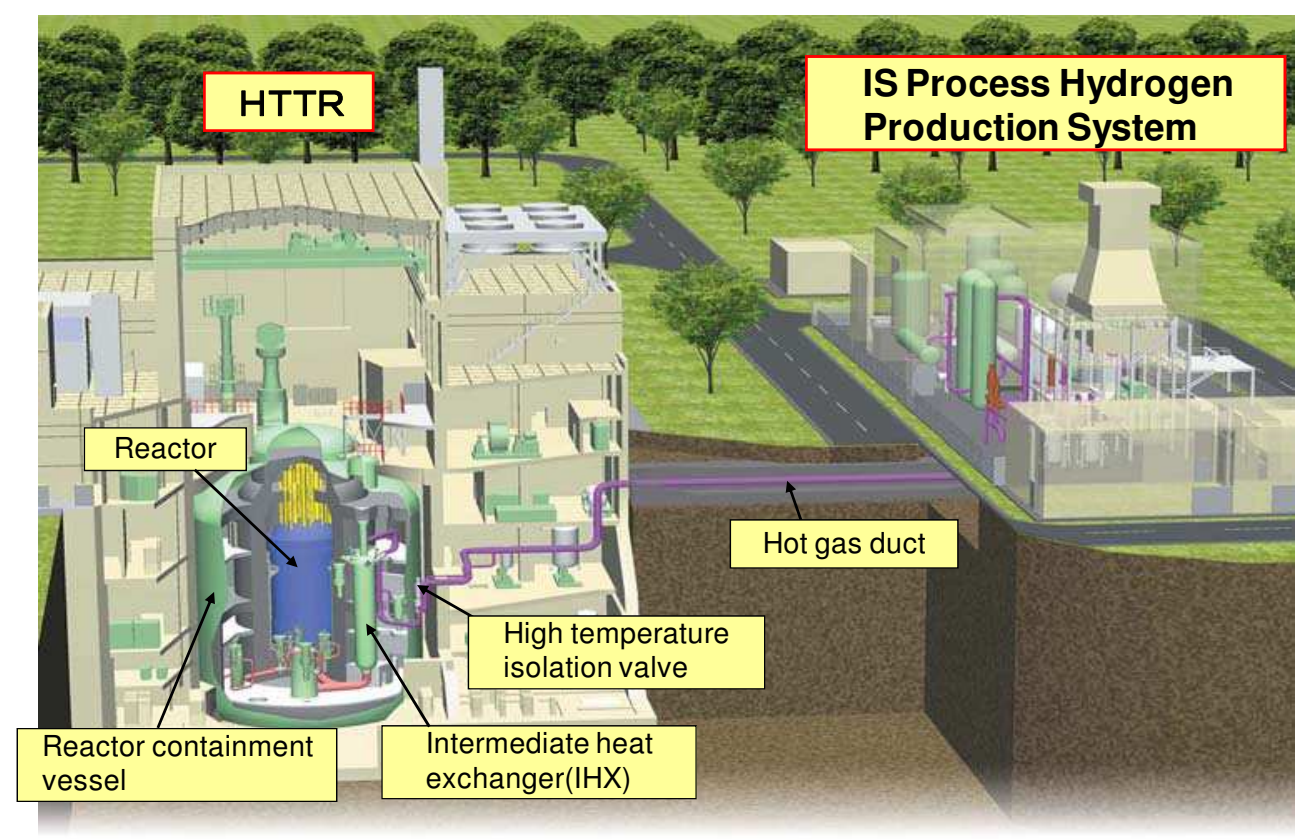

Fig. 15. Demonstration of nuclear hydrogen production by the IS process connected with HTTR

\section{Conclusions}

1. More than 10 billion tons of oil equivalent energy are consumed a year in the world in the present time, in which over $80 \%$ is provided by fossil fuels. Energy consumption is projected to increase by $60 \%$ in 2030 and by $240 \%$ in 2100, mostly in the developing countries despite a protected shortage of fossil fuels, especially oil and natural gas, within a few decades. On the other hand, consumption of large amounts of fossil fuels may have influenced global climate change. We will face the most serious consequences of climate change unless we stabilize the atmospheric concentrations of global greenhouse gases (GHG) considering and adopting the goal of achieving at least $50 \%$ reduction of GHG emissions to the present figure by 2050 .

2. Nuclear energy must play an essential role in reducing the dependence on fossil fuels and hence $\mathrm{CO}_{2}$ emissions, together with recognition of importance of renewable energy. Therefore, a growing number of countries have recently expressed their interests in nuclear power programs, so it is said that time is "Nuclear Renaissance". Nuclear energy can contribute as means to energy security and reduction of $\mathrm{CO}_{2}$ emissions not only through electricity generation but also by heat application in various industries such as steel making, 
chemical and petrochemical industries, together with hydrogen production for transportation, for example. Commercialization of High Temperature Gas-cooled Reactor ( HTGR) that can produce very high temperature heat of about $1000{ }^{\circ} \mathrm{C}$ based on the existing technologies will be vital to the realization of these goals, because HTGR is characterized by its flexibility of system design enable to meet heat application demands in various industries of non-electricity fields. We should expand utilization of nuclear energy to non-electricity fields which holds about $60 \%$ of total energy consumption.

\section{References}

[1] IPCC Fourth Assessment Report, November, 2007.

[2] World Population Prospects, 2006 Revision (UN).

[3] Energy Balances of OECD Countries and Energy Balances of Non-OECD Countries 2005-2006.

[4] BP Statistical Preview of World Energy, June, 2009.

[5] OECD/NEA and IAEA, Uranium, 2007.

[6] OECD/IEA, World Energy Outlook, 2006.

[7] REN21(2009) Global Status Report 2009 Update

[8] IEA, Agency for Natural Resources and Energy 2009

[9] IPCC “Special Report on Carbon Capture and Storage, 2010.

[10] Japan Atomic Industrial Forum, Inc., World Nuclear Power Plants, 2006.

[11] Central Research Institute of Electric Power Industry Report.

[12] http://www.eurnuclear.org/info/npp-ww.htm.

[13] http:/ / www.world-nuclear.com/info/default.aspx?id=27636\&terms=World+Nuclear.

[14] S. Saito et al., JAERI 1332, September, 1994.

[15] S. Saito, Report IAEA-TECDOC-761, 1994.

[16] K. Onuki et al., Energy Environ. Sci. 2 (2009).

[17] T. Inoue et al., Genshiryoku Eye 53 (4) (2007) (in Japanese).

[18] B.C.R. Ewan and R.W.K. Allen, Int. J. Hydrogen Energy 30 (2005).

[19] H.J. Hamel et al., Proc. of the ICONE14, Paper No. 89035 (2006).

[20] C.O. Bolthrunis et al., Proc. of the HTR2006, Paper No. I00000118 (2006).

[21] M.G. McKellar et al., Proc. of the ICONE14, Paper No. 89694 (2006).

[22] W.S. Summers et al., Proc. of the ICAPP'06, Paper No. 6107 (2006).

[23] X. Yan. et al., Proc. of the OECD/NEA 3rd Information Exchange Meeting on the Nuclear Production of Hydrogen, OECD/NEA, 121 (2005).

[24] T. Nishihara et al., AESJ Transaction 3 (4) (2004).

[25] S. Saito, J. Atom. Energy Soc. Jpn. 51 (2) (2009) (in Japanese). 


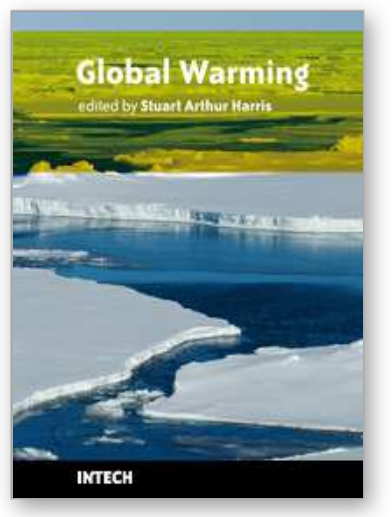

\author{
Global Warming \\ Edited by Stuart Arthur Harris
}

ISBN 978-953-307-149-7

Hard cover, 250 pages

Publisher Sciyo

Published online 27, September, 2010

Published in print edition September, 2010

This book is intended to introduce the reader to examples of the range of practical problems posed by "Global Warming". It includes 11 chapters split into 5 sections. Section 1 outlines the recent changes in the Indian Monsoon, the importance of greenhouse gases to life, and the relative importance of changes in solar radiation in causing the changes. Section 2 discusses the changes to natural hazards such as floods, retreating glaciers and potential sea level changes. Section 3 examines planning cities and transportation systems in the light of the changes, while section 4 looks at alternative energy sources. Section 5 estimates the changes to the carbon pool in the alpine meadows of the Qinghai-Tibet Plateau. The 11 authors come from 9 different countries, so the examples are taken from a truly international set of problems.

\title{
How to reference
}

In order to correctly reference this scholarly work, feel free to copy and paste the following:

Shizu Saito, Masuro Ogawa and Ryutaro Hino (2010). Role of Nuclear Energy to a Low Carbon Society, Global Warming, Stuart Arthur Harris (Ed.), ISBN: 978-953-307-149-7, InTech, Available from: http://www.intechopen.com/books/global-warming/role-of-nuclear-energy-to-a-low-carbon-society

\section{INTECH}

open science | open minds

\section{InTech Europe}

University Campus STeP Ri Slavka Krautzeka 83/A 51000 Rijeka, Croatia Phone: +385 (51) 770447 Fax: +385 (51) 686166 www.intechopen.com

\section{InTech China}

Unit 405, Office Block, Hotel Equatorial Shanghai No.65, Yan An Road (West), Shanghai, 200040, China 中国上海市延安西路65号上海国际贵都大饭店办公楼405单元 Phone: +86-21-62489820

Fax: +86-21-62489821 
(C) 2010 The Author(s). Licensee IntechOpen. This chapter is distributed under the terms of the Creative Commons Attribution-NonCommercialShareAlike-3.0 License, which permits use, distribution and reproduction for non-commercial purposes, provided the original is properly cited and derivative works building on this content are distributed under the same license. 